\section{VIDEo Hemiballism due to sildenafil use}

Itxaso Martí, MD, and J.F. Martí Massó, MD, PhD, San Sebastián, Spain

Two patients have had intracerebral hemorrhage as a side effect of sildenafil; we present the third, who experienced hemiballism..$^{1,2}$

A 62-year-old man with hypertension was admitted with sudden brisk movements of the left limbs. He recently had taken 50 $\mathrm{mg}$ of sildenafil and had sexual intercourse with his wife.

The neurologic examination revealed hemiballism of his left limbs (see video clip on the Neurology Web site). The admission blood pressure was $160 / 85 \mathrm{~mm} \mathrm{Hg}$. CT imaging revealed a small hemorrhage in the right subthalamic-thalamic region (figure). The patient was treated with tetrabenazine, $200 \mathrm{mg} /$ day, for $<1$ month; abnormal movement decreased progressively (see video clip on the Neurology Web site).

In this patient there was a clear relationship between sildenafil and the hemorrhage with secondary hemiballism. The increase of blood flow in the intracerebral vessels associated with sexual intercourse facilitated the hemorrhage in a patient with other hemorrhagic risk factors.

1. Monastero M, Pipia C, Camarda L. Intracerebral haemorrhage associated with sildenafil citrate. J Neurol 2001:248:141-142.

2. Buxton N, Fannery T, Wild D. Sildenafil (Viagra) -induced spontaneous intracerebral haemorrhage. Br J Neurosurg 2001;15:347-349.

Additional material related to this article can be found on the Neurology Web site. Go to www.neurology.org and scroll down the Table of Contents for the August 10 issue to find the title link for this article.

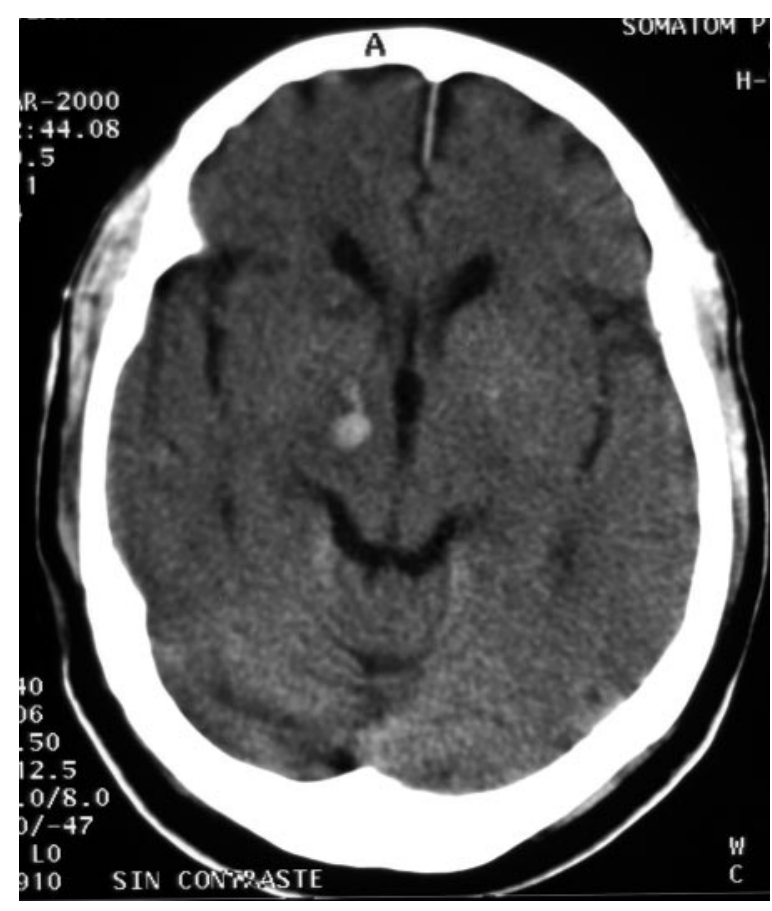

Figure. CT scan: small hemorrhage in the subthalamic area.

Address correspondence and reprint requests to Dr. J.F. Martí Massó, Paseo Dr. Beguiristain s/n, 20014 San Sebastián, Spain; e-mail: jfmarti@chdo.osakidetza.net 


\title{
Neurology
}

\author{
Hemiballism due to sildenafil use \\ Itxaso Martí and J. F. Martí Massó \\ Neurology 2004;63;534
}

DOI 10.1212/01.WNL.0000130359.58099.8B

This information is current as of August 9, 2004

\section{Updated Information \& \\ Services}

Supplementary Material

\section{References}

Citations

Subspecialty Collections

Permissions \& Licensing

Reprints including high resolution figures, can be found at:

http://n.neurology.org/content/63/3/534.full

Supplementary material can be found at:

http://n.neurology.org/content/suppl/2004/07/13/63.3.534.DC1

http://n.neurology.org/content/suppl/2004/07/13/63.3.534.DC2

This article cites 2 articles, 0 of which you can access for free at: http://n.neurology.org/content/63/3/534.full\#ref-list-1

This article has been cited by 1 HighWire-hosted articles: http://n.neurology.org/content/63/3/534.full\#\#otherarticles

This article, along with others on similar topics, appears in the following collection(s):

\section{All Cerebrovascular disease/Stroke}

http://n.neurology.org/cgi/collection/all_cerebrovascular_disease_strok e

All Movement Disorders

http://n.neurology.org/cgi/collection/all_movement_disorders

Intracerebral hemorrhage

http://n.neurology.org/cgi/collection/intracerebral_hemorrhage

Information about reproducing this article in parts (figures,tables) or in its entirety can be found online at:

http://www.neurology.org/about/about_the_journal\#permissions

Information about ordering reprints can be found online:

http://n.neurology.org/subscribers/advertise

Neurology ${ }^{\circledR}$ is the official journal of the American Academy of Neurology. Published continuously since 1951, it is now a weekly with 48 issues per year. Copyright . All rights reserved. Print ISSN: 0028-3878. Online ISSN: 1526-632X.

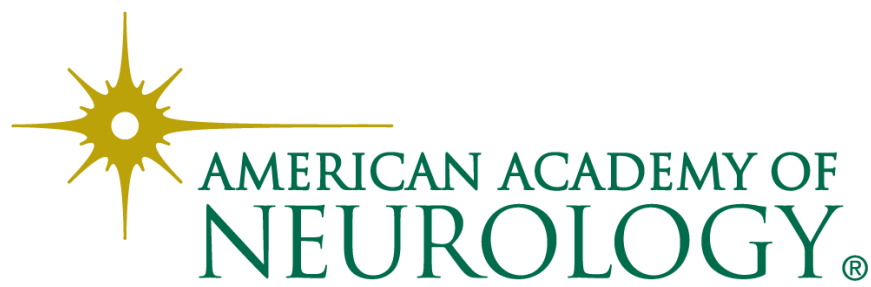

